\title{
Aşçıların Beş Faktör Kişilik Özellikleri, Bireysel İnovasyon Algıları ve Bireysel İnovasyon Davranışları Arasındaki İlişkiler \\ (The Relationship Between Five Factor Personality Traits, Individual Innovation \\ Perceptions and Individual Innovation Behaviors of Cooks)
}

\section{Seydi Ahmet ÇETiN (Da Bayram ŞAHIN}

a Zübeyde Hanım MTAL, Osmangazi, Bursa, Türkiye. seydiahmetcetin@hotmail.com

b Balıkesir Üniversitesi, Turizm Fakültesi, Balıkesir Türkiye. bsahin@balikesir.edu.tr

\begin{tabular}{|c|c|}
\hline MAKALE BİLGİSI & ÖZET \\
\hline $\begin{array}{l}\text { Anahtar Kelimeler: } \\
\text { Turizm } \\
\text { Otel }\end{array}$ & $\begin{array}{l}\text { Amaç - Araştırmanın amacı otel mutfaklarında çalışan aşçıların kişilik özellikleri ile bireysel } \\
\text { inovasyon davranışı arasındaki ilişkilerin belirlenmesi ve bu iki değişken arasında bireysel } \\
\text { inovasyon algısı boyutlarının aracılık etkisinin incelenmesidir. }\end{array}$ \\
\hline $\begin{array}{l}\text { Gönderme Tarihi } 15 \text { Ocak } 2019 \\
\text { Revizyon Tarihi } 20 \text { Mart } 2019 \\
\text { Kabul Tarihi } 24 \text { Mart } 2019\end{array}$ & $\begin{array}{l}\text { Yöntem - Araştırma evrenini, Bursa'daki dört ve beş yıldızlı otellerde çalışan } 281 \text { aş̧̧ı } \\
\text { oluşturmaktadır. Toplanan } 246 \text { anketten uç değerler ve yüksek miktarda eksik veri içerenler } \\
\text { çıkarıldıktan sonra, toplam } 220 \text { adet kullanılabilir anket formu elde edilmiştir. Araştırmada beş } \\
\text { faktör kişilik özellikleri envanteri, bireysel inovasyon algısı ve bireysel inovasyon davranışı } \\
\text { ölçekleri kullanılmıştır. Kullanılan ölçeklere Cronbach Alfa Güvenilirlik Katsayısı ve Aç1klayıı } \\
\text { Faktör Analizi uygulanmıştır. Literatürden elde edilen bilgiler doğrultusunda toplam } 4 \text { hipotez } \\
\text { kurulmuş ve bu hipotezler, pearson korelasyonu ve çoklu regresyon analizleri ile test edilmiştir. }\end{array}$ \\
\hline $\begin{array}{l}\text { Makale Kategorisi: } \\
\text { Araştırma Makalesi }\end{array}$ & $\begin{array}{l}\text { Bulgular - Beş faktör kişilik özelliklerinden deneyime açıklık faktörünün olumlu yönde, } \\
\text { duygusal dengesizlik faktörünün ise olumsuz yönde bireysel inovasyon davranışı üzerinde } \\
\text { anlamlı etkisi olduğu bulgusuna ulaşılmıştır. Deneyime açı kişilik özelliğini daha fazla } \\
\text { gösteren aşılların bireysel inovasyon davranışları olumlu yönde olurken, duygusal dengesizlik } \\
\text { özelliğine sahip olanlarda ise olumsuz bir etkilenim söz konusudur. Diğer kişilik özelliklerinin } \\
\text { bireysel inovasyon davranışlarında anlamlı bir etkisi bulunmamaktadır. Ayrıca; sadece olumlu } \\
\text { bireysel inovasyon algısının beş faktör kişilik özellikleri ile bireysel inovasyon davranışı } \\
\text { ilişkisine kısmi aracılık ettiği sonucuna ulaşılmıştır. }\end{array}$ \\
\hline & $\begin{array}{l}\text { Tartışma - Elde edilen bulgular literatürle benzer sonuçlara ulaşıldığını göstermektedir. Özgün } \\
\text { olarak olumlu bireysel inovasyon algısı beş faktör kişilik özellikleri ile bireysel inovasyon } \\
\text { davranışı ilişkisinde kısmi aracılık etkisi göstererek aşçılardan beklenen inovatif davranışlarda } \\
\text { inovasyon algılarının dikkate alınması gerektiğini ortaya koymaktadır. }\end{array}$ \\
\hline
\end{tabular}

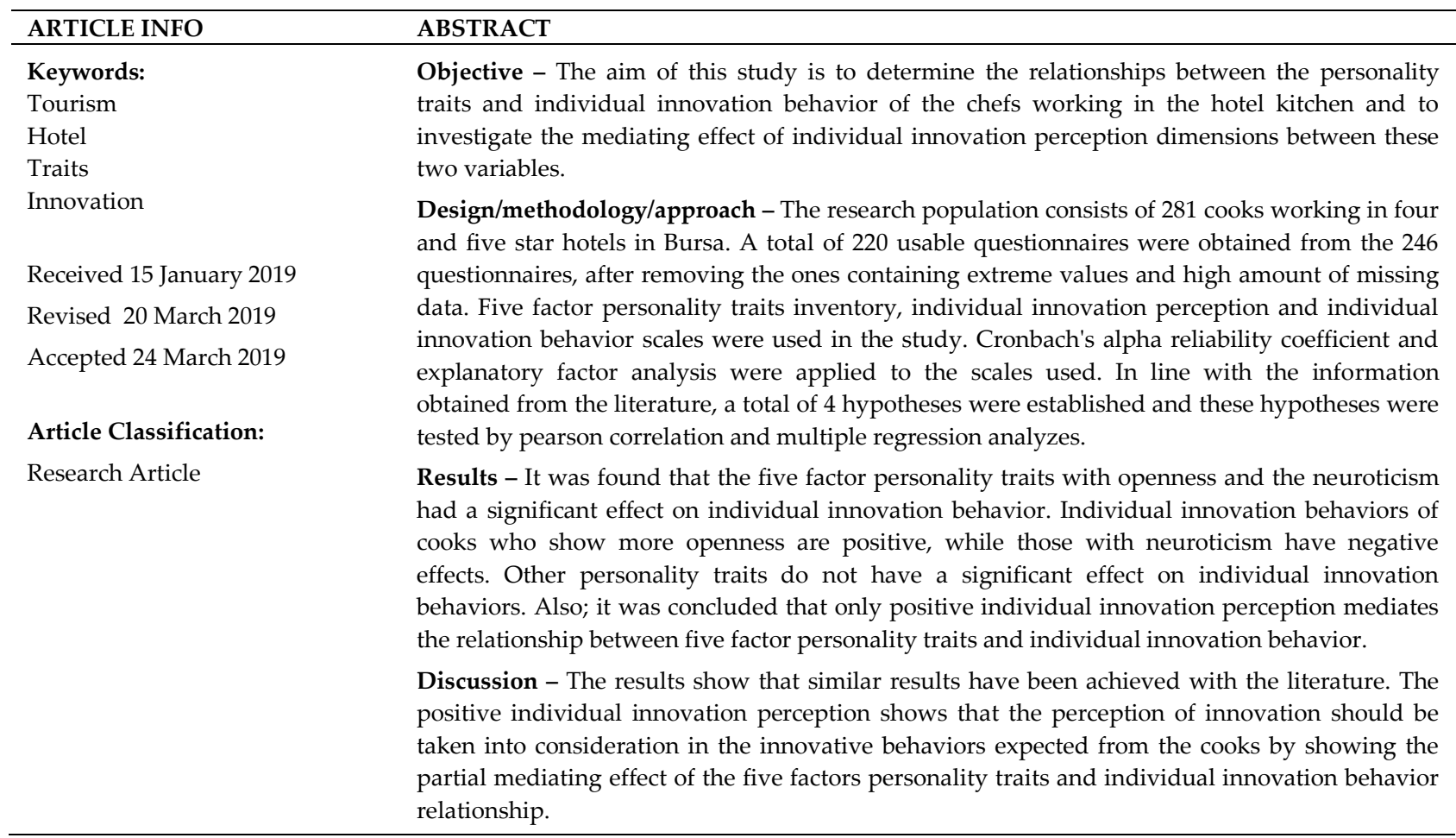




\section{GİRiş}

“İşgörenlerin örgüt içindeki bir takım uygulama, süreç ve davranışlara karşı çeşitli tutum ve davranışlar geliştirmesi, bir başka deyişle çeşitli durumları farklı algılayarak farklı tepkiler göstermesi insan kaynağının örgütsel amaçlar doğrultusunda yönlendirilmesini zorlaştırmaktadır" (Çetin, 2009 :1). İnsan davranışları farklı kişilik özelliklerine göre değişebilmektedir. Kişilik özelliklerinin mutfaklarda üretilen yiyecek ve içeceklere yansıması geleneksel ve inovatif davranışlar doğrultusunda olabilmektedir. Mutfaklarda üretilen yiyecek içeceklerin yanında kullanılan araç-gereç ve ekipman seçimi, personel seçimi, yönlendirilmesi ve yönetimi, üretim süreçleri vb. insan unsurundan etkilenebilmektedir. Ayrıca; mutfaklarda inovasyon, geleneksel yöntemlerle pişirilen yemeklere inovatif karakterler eklenmesi, yeşil üretim süreçlerinin oluşturulması, rafine mutfak uygulamaları gibi anlayışların benimsenerek örgütsel amaçlara hizmet edilmesi, özellikle farklılık yaratılarak daha rekabet edilebilir bir ortam oluşturulması gibi hususlardan dolayı önemlidir. "Hem bir süreci (yenilemeyi- yenilenmeyi) hem de bir sonucu (yenilik)" (Eraslan, Bulu ve Bakan, 2008 :10) içeren inovasyon kavramı beş faktör kişilik özellikleri ile beraber işletmelerin özellikle insan kaynaklarının seçimi ve geliştirilmesi açısından üzerinde düşünmeleri gereken kavramlar olarak karşımıza çıkmaktadır. Otel işletmelerinde sunulan yiyecek ve içeceğin baş aktörlerinin aşçılar olduğu düşünüldüğünde bu kişilerin nitelikleri örgütsel amaçlar açısından son derece önem arz etmektedir ve bundan dolayı otel mutfaklarında çalışan aşçılar mevcut araştırmanın örneklemini oluşturmaktadır. Aşçıların kişilik özelliklerine göre inovasyon algı ve davranışlarının anlaşılması önemli olup, özellikle farklı kişiliğe sahip aşçıların bireysel inovasyon algılarının bireysel inovasyon davranışlarına nasıl etkiler yapacağı bilinmelidir. Diğer bir ifadeyle, inovasyon algısı; aracı değişken olarak bağımsız bir değişkenin (aşçıların beş faktör kişilik özellikleri), bağımlı bir değişken (inovasyon davranışı) üzerindeki etkisini arttırabilir veya azaltabilir. Mevcut araştırma, bu eksikliği gidermek için bireysel inovasyon davranışlarını hangi kişilik özelliklerinin daha çok etkilediği ve özgün olarak bireysel inovasyon algılarının beş faktör kişilik özellikleri ile bireysel inovasyon davranışları arasındaki aracılık etkisini inceleyerek literatüre katkı sağlamayı amaçlamaktadır.

\section{KAVRAMSAL ÇERÇEVE}

\section{Beş Faktör Kişilik Özellikleri}

“Beş faktör modeli uzun bir geçmişi olan yeni bir bakış açısı olarak görülebilir. Önceki nesil bakış açılarından farklı olarak teoriye değil, bilimsel gözleme dayalı olup, kişiliği beş temel boyutta ele alır. İnsanları kategorilere bölmektense çeşitli kişilik boyutlarında farklı düzeylere yerleştirir" (Girgin, 2007:73). Beş Faktör Kişilik Kuramı'nın altında yatan temel varsayım, bireysel farklılıklarının tüm dünyada bütün dillerde kodlanabileceği, konuşma diline sözcükler halinde yansıyacağı ve bu sözcüklerden yola çıkarak insanın kişilik yapısını gösteren bir sınıflandırmanın yapılabileceğidir. Bu kuram; “taraftarlarının değer biçtikleri, muhtemel veriler, bağıntılı tasvirler; farklılıkları yönetme, davranış ve grupsallıkla bireysellik arasında" varolan tepki ile açıklanmaktadır (Demirci, Özler ve Girgin, 2007:21-22).

Kişiliğin beş boyutta açıklanması çalışmaları altmışlı yıllarda başlamış, seksen ve doksanlarda bu tür çalışmalar hız kazanmıştır (Tekin, 2012:119). Kuramın öncülerinden biri olan Goldberg, sözlükteki sıfatlara dayalı olarak yaptı̆̆ çalışmada kişilik özelliklerini açıklayan beş ana faktörün ortaya çıktığını belirtmiş ve kişilik araştırmalarının bu beş ana faktör çerçevesinde organize edilebileceğini ileri sürmüştür. Tupes ve Christal ise Cattel'in bulgularını tekrar analiz ederek beş temel faktörü ortaya koymuşlardır. Norman ise çeşitli analizler sonucunda yine beş faktörün en iyi çözümü verdiğini belirtmiştir. İlk dört faktör Norman'ın faktörleri ile oldukça uyumlu ve açık bir şekilde ortaya çıarken, beşinci faktör, Norman'ın kültür faktöründen farklı olarak, açık fikirlilik, bağımsızlık ve değişiklik ihtiyacı, orijinallik ve yaratıcılık gibi kişilik özelliklerini kapsayan deneyime açıklık boyutu olarak yorumlanmıştır. Daha sonra McCrae ve Costa yaptıkları çeşitli çalışmalarla beş faktörü bulmuşlar, sadece beşinci faktörü Zekâ/Deneyime Açıklık olarak tanımlamışlardır (Goldberg, 1993:31). Goldberg ise beş faktör yapısı ile ilgili yapmış olduğu çalışmalar neticesinde, beş faktör yapısını daha da geliştirerek biri elli diğeri yüz maddeden oluşan iki adet ölçek ortaya çıkarmıştır, bu şekilde Goldberg'in tanımlamış olduğu şu beş faktör ortaya çıkmıştır; uyumluluk, sorumluluk, duygusal denge, içe-dışa dönüklük, entelektüel hayal gücü (Apple, 2011, akt., Tekin, 2012:119). Bolat'a (2008) göre; ayırıcı özellikler yaklaşımını benimseyen kuramcılardan Costa ve McCrae (1985), tarafından, "faktör" adını verdikleri davranış değişkenlerinin büyük insan gruplarının çok yönlü ölçümü ve 
puanlaması sonucunda, kişiliğin beş faktörden oluştuğu belirlenmiştir (Tekin, 2012:119). Costa Jr ve McCrae, daha sonraki çalışmaları neticesinde, Beş Faktör Modeli'nin beş ana boyutunu; dışadönüklük, duygusal dengesizlik, geçimlilik, açıklık ve sorumluluk şeklinde tanımlamışlardır (Somer ve Goldberg, 1999:431-450). Günümüzde ise artık beş büyükler olarak kabul edilmiş ve beş faktör kişilik özelliklileri kuramı olarak uzlaşmaya varılmıştır (Yeni, 2015:20). Bugün evrensel anlamda kabul görmüş beş faktör kuramının ana boyutları İngilizce baş harfleri olan "OCEAN" olarak da bilinmektedir. "O" Openness-Deneyime Açılık faktörünü, "C" Conscientiousness-Sorumluluk faktörünü, "E" Extraversion-Dışa Dönüklük faktörünü, "A" Agreeableness- Uyumluluk faktörünü, " $N$ " ise Neuroticism-Duygusal Dengesizlik kavramını ifade etmektedir. Burada araştırmacıların bazı kavramları farklı isimlendirme çalışmaları da görülmektedir. Sorumluluk faktörü bazı kaynaklarda Öz-Disiplin, Vicdanlılık gibi isimlerle; duygusal dengesizlik kavramı, duygusal denge, duygusal istikrar, nevrotiklik, duygusal değişkenlik, duygusal tutarlılık gibi isimlerle; Uyumluluk faktörü ise yumuşak başlılık, uzlaşılabilirlik, geçimlilik, zeka, akıl gibi isimlerle anılabilmektedir. Deneyime Açıklık faktörü yerine "Açıklık" ismi de kullanılmaktadır.

Kişilik özelliklerinin tanımlanmasına yönelik olarak geliştirilmiş olan beş faktör kişilik kuramı, kişiliğe dair nitelikleri beş ayrı boyut vasıtasıyla ve bu boyutlara bağıl 30 alt boyutla tanımlar. Modeldeki ana boyutlar, birçok araştırmacının önermiş olduğu yüzlerce benlik özelliğinin incelenmesiyle belirlenmiştir (Demirci vd. 2007; Güneş, 2016:17). Beş faktör, kişilik modelinde yer alan her boyut birbirine zıt iki kutuplardan oluşmuştur. Her boyut ise, bir takım çoklu alt kategorilerden oluşmuştur. Örneğin, dişadönüklük boyutu, içedönük ve dışadönük olmak üzere iki yöne sahiptir. Ayrıca, dışadönüklük boyutu sessiz-konuşkan, soğukcana yakın, utangaç-spontan ve çekingen-atılgan alt boyutlarını kapsamaktadır (Mischel, 1999, akt., Yıldırım, 2014:28). Her bir boyuta ilişkin ifadeler her iki ucu da kapsayacak şekilde düzenlenmeli ve elde edilen sonuçlar negatif ve pozitif uçlar dikkate alınarak değerlendirilmelidir. Burada ölçülen özelliğin kuramda belirtilen ayırıcı özelliğinden dolayı baskın olmasını ifade etmektedir. Böylece; bireyin kişiliği hakkında bir yargıya ulaşılabilmektedir.

\section{Bireysel İnovasyon}

İnovasyon kavramı TDK'da (2018) "yenileşim" olarak tanımlanmaktadır. Yenileşim kavramı ise, değişen koşullara uyabilmek için toplumsal, kültürel ve yönetimsel ortamlarda yeni yöntemlerin kullanılmaya başlanması, yenilik, inovasyon (TDK 2018) olarak açıklanmaktadır. Yenileşim kavramının çok sık kullanılmadığı, onun yerine "yenilikçilik" kavramının Türkçe literatürde daha geniş yer bulduğu görülmüştür. Ancak; bu çalışmada yenileşim ve yenilikçilik kavramları yerine daha çok bilinen ve sık kullanılan bir kavram olmasından dolayı "inovasyon" kavramı kullanılacaktır. Ayrıca; genellikle yenilik kavramının da inovasyonun ifade ettiği anlamların tamamını kapsamadığı için inovasyon yerine kullanılamayacağı kabul edilmektedir. Çünkü her yeni olan bir inovasyon olarak değerlendirilememektedir. İnovasyonun temel dinamiğinde sadece yeni olan değil, ekonomik ve sosyal bir katma değere dönüşen veya dönüştürülen yenilikler bulunmaktadır (Uzkurt, 2010:37). Peter Drucker'a göre ise, bir yöneticinin düşebileceği en büyük tuzaklardan biri inovasyonla (innovation) yeniliğin (novelty) birbiriyle karıştırılmasıdır. İnovasyon, "yenilikten farklı olarak, değer yaratır" (Elçi, 2007:2). Bunun dışında inovasyon ile karıştırılabilecek başka kavramlar da mevcuttur. İnovasyon kavramına benzer birden fazla kavram bulunmaktadır. Buluş ya da icat, yaratıcılık, Ar-Ge benzer kavramlara örnek verilebilir. Bu kavramlar genellikle birbirlerinin yerine sıklıkla yanlış şekilde kullanılabilmektedirler. İnovasyon kavramı genelde buluş ya da icat kavramlarıyla karıştırılmaktadır. Aslında bu kavramlar yakın ilişkili olmasına rağmen birbirlerinden farklıdır. Basit tanımıyla icat etmek; muhakkak keşfedilmemiş yeni bir şeyler oluşturmak, yeni bir fikrin oluşturulmasıdır. İnovasyon ise keşfedilmemiş olanı icat etmeyi değil; henüz yapılmamış bir şeyi yapmak ya da yapılmış olanı farklılaştırmaktır. İnovasyon için buluşlardan yararlanılabilir fakat buluşlar her zaman inovasyon olarak karşımıza çıkmaz. Çünkü inovasyon ticari bir başarı gerektirir. Buluş ise ticarileştirilemediği sürece inovasyon olmaz. Buluşun inovasyon olabilmesi için katma değer oluşturması gerekmektedir (Elçi, 2007). Harrison ve Enz'e (2005:287) göre ise inovasyon, "icat ve ticarileşmenin bileşenidir ve yenilikçi bir işletme bir fikri müşterilerin istediği bir ürün ve hizmete dönüştürmeyi bilmelidir" (Tekin ve Durna, 2012:94). Durna'ya (2002:8) göre; “yaratıcıllk, yeni fikirlerin oluşturulması ile ilgiliyken, inovasyon bu fikirleri ürün veya hizmete dönüştürme süreciyle ilgilidir. İnovasyonun başlangıç noktası yaratıcllıktır. Yaratıcılık, yeni fikirler oluşturma ya da mevcut fikirlere yeni bakış açıları getirme yeteneğidir. Yeni fikirlerin oluşturulması için gerekli olan yetenekler ile bunları uygulamak için gerekli olan 


\section{S. A. Çetin - B. Şahin 11/1 (2019) 706-719}

yetenekler birbirinden farklıdır. Yeni fikirlerin kullanılabilir hale getirilmesi için hem yaratıcı hem de yenilikçi personele ihtiyaç vardır. Yaratıcı fikirler uygulamaya konmadıkça işletme için hiçbir değer yaratmaz ve anlam ifade etmez. Bu bakımdan, işletmelerde inovasyon sürecinin, hem yaratıcılığı hem de yenilikçiliği kapsaması gerekmektedir" (Cengiz, 2012:24). Hall ve Williams'a (2008:21) göre; "her şeyden önce inovasyon bir ekonomik süreçtir. Sonunda bir ürün de olabilir, bir hizmet de, daha gelişmiş bir yönetim modeli de. İnovasyonda tesadüfe de yer yoktur. Öncelikle gerekli bilgi birikiminin oluşması gereklidir. ARGE (Araştırma-Geliştirme) ile inovasyonu da karıştırmamak gerekir. Her araştırma, olumlu sonuç verse dahi, inovasyona yol açmaz. Ancak; AR-GE düzeyi yükselmeden inovasyonun gelişmesi de beklenmemektedir. İnovasyonun gelişmesi için araştırma önemlidir. Bilgi yaratma önemlidir. Teknik inovasyonda ise sanayinin katkısı gereklidir. Bundan böyle yeni bir terimi de kullanır olacaktır: AR-GE (Araştırma-Geliştirme)'nin yanında AR-İN (Araştırma-inovasyon). İnovasyon sonunda bir yenilik getirmeyebilir. Belki sadece bir değişimdir. Onun için "yenilikçilik" sözcüğü "inovasyon" un tam karşıllı̆g değildir" (Üstel ve Kabatepe, 2006:9, akt., Cengiz, 2012:21,22; Vatan ve Zengin, 2014:513).

İnovasyon; bireysel inovasyon ve grupsal inovasyon olarak iki grupta incelenebilir. Bireysel inovasyon, işletmedeki çalışan bireylerin işinde faydalı olabilecek yeni fikirleri, süreçleri, ürünleri ve prosedürleri uygulama konusundaki gayretleridir. Grupsal inovasyon ise, farklı şekillerde oluşturulmuş, uyarlanmış fikirleri grup içerisinde değerlendirerek, gerekirse yeniden düzenleyerek uygulanabilir şekile getirilerek hayata geçirilmesidir (Özçer, 2005:53-55; Yıldız, 2017:4). Bireysel inovasyon kavramı çerçevesinde literatürde bireyin kişilik özellikleri, yeniliği kabullenme ve kullanmaya yönelik olan davranışları üzerinde durulmaktadır (Şentürk vd., 2016:178). Bu anlamda bireysel inovasyon Sarığlu (2014:24)'e göre “herhangi bir ürünün, hizmetin ya da fikrin bir kişi tarafından yeni olarak algılanması" ve Yuan ve Woodman (2010: 333)'a göre "bir yeniliğin geliştirmesi, kabul edilmesi ya da uygulaması" olarak tanımlanmaktadır. Kılıçer'e (2011:23) göre ise bireysel inovasyon, "bireyin yeni olan şeylere istekliliğini, onları benimsemesini, kullanmasını ya da yararlanmasını" ifade etmektedir. Araştırmanın aracı değişkeni olan ve inovasyon sürecini şekillendiren değişken, bireysel inovasyon algısıdır. Rogers (2003:134) bir fikir veya ürünün yenilik olarak değerlendirebilmesi için uygulayıcının ilk veya öncü olmasına bakılmadığının altını çizmiştir. Rogers, inovasyonların, bireyler veya uygulayıcıları tarafından ilk olarak algılanması gerektiğini ifade etmiştir. İşverenlerin ve işyerinde çalışanların, kalite, beklenti, üretim vb. hakkında farklılaşan algılamaları bulunabilir. Bu durumun söz konusu olduğu ortamlar, işletmelerin amaçlarını gerçekleştirmesi birtakım zorlukların ortaya çıkmasına sebep olacaktır (Otara, 2011:21, akt., Torun, 2016:24).

\section{LITERATÜR TARAMASI}

İnovasyon kavramının teorik temelleri yüzyıla yakın iken turizmde inovasyon kavramının 21. yüzyıl ile beraber ancak hız kazandığı söylenebilir. Konu ile ilgili literatür incelendiğinde turizm sektöründe beş faktör kişilik özellikleri ile inovasyon davranışları arasındaki ilişkileri inceleyen çok fazla çalışmaya rastlanmamıştır ancak; Bakx (2007) ile Yeşil ve Sözbilir (2013) kişilik özellikleri ile inovasyon davranışları arasında bir ilişkiden söz etmektedirler. Her iki araştırmanın otel işletmelerindeki çalışanlara yönelik yapıldığı göz önüne alındığında özellikle Bakx'da (2007) deneyime açıklık ile duygusal dengesizlik alt boyutlarının inovasyon davranışının önemli belirleyicileri oldukları belirtilirken Yeşil ve Sözbilir'de (2013) deneyime açıklık dışında diğer dört kişilik faktörünün bireysel inovasyon davranışı ile ilişkili bulunmadığı bildirilmektedir. "Türkçe alan yazında konaklama işletmeleri, yiyecek ve içecek işletmeleri ve seyahat acentalarında inovasyon üzerine odaklanan oldukça sınırlı sayıda araştırmanın bulunduğu görülmektedir" (Erdem, Gökdeniz ve Met, 2011 :79). “Uluslararası alan yazında inovasyon ve bireysel inovasyon üzerine yapılmış çalışmalar (Ar, 2012; Arungai, 2015; Chen, Lai ve Wen, 2006; Chen, Lin ve Chang, 2009; Chiou, Chan, Lee ve Hsieh, 2010; Coşkun, Mesci ve Kılınç, 2013; Epetimehin, 2011; Hana, 2013; Lettice ve Chung, 2011; Ren, Xie ve Krabbendam, 2010) bulunmakla birlikte, bu çalışmaların büyük çoğunluğunun imalat sanayi örnekleminde yapıldığı görülmektedir" (Çakıcı, Çalhan ve Karamustafa, 2016 :12). Işık ve Türkmendağ (2016) ise öğrencilerin bireysel yenilikçilik algılarını ölçtüğü çalışmasında fikir önderliği, risk alma ve değişime direnç algısı boyutları tespit etmiştir ve bu çalışmadaki olumlu algı, olumsuz algı ve direnç algısı boyutlarıyla benzerlik göstermektedir. King, McKee Walker ve Broyles (1996), yaratıcı bireyin özelliklerinin, deneyime açıklık ile yakından ilişkili olduğu, deneyime açıklığın diğer dört faktörle karşılaştırıldığında yaratıcılık ile en yüksek korelasyona sahip olduğunu ve deneyime kapalı insanların yüksek yaratıcılık becerilerine sahip olsa bile düşük yaratıcı davranışlar sergilediklerini ileri sürmüştür. 
George ve Zhou (2001) deneyime açıklık kişilik özelliğini daha fazla gösteren insanların her zaman yaratıcı davranışlar gösteremeyeceğini, çünkü yaratıcı davranışların "geribildirim vaadi ve sezgisel görevler" gibi durumsal faktörlere de bağlı olduğunu, deneyime açık bireylerin, yüksek geri besleme değerlerine ihtiyaç duyduklarını, bunun da olumlu geri bildirim ve sezgisel görevler anlamına geldiğini ileri sürmektedir. Mevcut araştırmada deneyime açk bireylerin daha yenilikçi davranışlar sergileyeceği düşüncesi öngörülmektedir. Değişime karşı direnç, kurallara ve örgütsel normlara uyum ve önceden belirlenmiş hedeflere ulaşma çabası olarak nitelendirilen yüksek sorumluluğun (Conscientiousness) yenilikçi davranış üzerinde olumsuz bir etkiye sahip olabilmektedir (George ve Zhou, 2001). Bakx (2007) ise yenilikçiliğin durumlarla başa çıkmanın yeni yollarını arayan ve mevcut normları umursamayan bireyler gerektirdiğini ileri sürmektedir. Barrick ve Mount (1991) yüksek sorumluluk sahibi insanların güvenilir, sorumlu, organize, çalışkan ve başarı odaklı olduklarını, Yeşil ve Sözbilir, (2007) Patterson vd.'nin (2009), duyarlılık ile ilişkili özelliklerin inovasyonla ilgili olmadığını iddia ettiğini; bunun yerine, sorumluluk azlığının, yenilikle ilişkili olabileceğinin önceki araştırmalarda da (Barron ve Harrington, 1981; Harrison vd., 2006; Rothmann ve Coetzer (2003), belirtildiğini iletmiştir. Konu ile ilgili yapılan literatür taraması sonucu elde edilen bilgiler ışığında olumlu ve olumsuz ilişkilerden söz edilmesine rağmen beş faktör kişilik özellikleri alt boyutlarından sorumlukluk ile bireysel inovasyon davranışları arasında negatif bir ilişki olacağı varsayılmaktadır. Patterson'a (2002) göre bazı araştırmacılar, dışadönüklük ve yenilik arasındaki ilişkiyi net bir şekilde ortaya koyacak yeterli delil olmadığını ileri sürmektedirler (Bakx, 2007). Örneğin; Gelade (2002) yenilikçilikle dışadönüklük arasında bir ilişkinin varlığını ileri sürmekte ancak; bu ilişkinin kesin sonuçlara varmak için çok karmaşık bir fikir olduğunu da belirtmektedir. Bakx (2007), farklı araştırmacıların yenilikçiliği, yeni alanlar yaratmada, yüksek bir enerji düzeyine ve fantaziye sahip olmada bir zevk olarak tanımladığını, bu yüzden yüksek bir dışadönüklük seviyesinin yüksek bir inovasyon düzeyiyle ilişkili olmasının beklenebileceğini belirtmiştir. Araştırmamızda da benzer şekilde beş faktör kişilik özelliklerinin alt faktörlerinden dışadönüklülügüün (Openness), bireysel inovasyon davranışına etki edeceği kabul edilmektedir. Bakx'da (2007), King vd.'nin (1996) uyumluluğun uygunluğa yol açabilirken, inovasyon düşüncesinin eylem ve özerkliğin bağımsızlığını gerektirdiğini, yenilikçi davranış için önemli olan bu özelliklerin de uyumsuzluk ile negatif ilişkiyi açıkladığını ileri sürmektedir. Yeşil ve Sözbilir'de (2013), Barrick ve Mount'un (1991) anlaşmazlıktan yüksek puan alan insanların iyi huylu, bağışlayıcı, kibar, yardımsever, özgecil, cömert ve işbirlikçi kişilik yapısında olduklarını ileri sürdüklerini; anlaşmazlık ve inovasyon arasında negatif bir ilişki olduğunu gösteren çeşitli çalışmalara (George ve Zhou, 2001; Gelade, 1997; Patterson, 1999) işaret ettiğini belirtmiştir. Patterson vd. (2009) duygusal dengesizliğin yenilikler üzerindeki etkilerine dair tutarsız sonuçların var olduğunu öne sürmüşlerdir (Yeşil ve Sözbilir, 2013). Ayrıca; konu ile ilgili literatürde duygusal dengesizlik ve inovasyon arasında olumlu ve olumsuz ilişkilerin bulunduğu, hem Patterson'un (2002) hem de King vd.'nin (1996) inovasyon ve duygusal dengesizlik arasındaki ilişkiyi belirleme zorluğunu tartıştıklarını, yüksek düzeyde bir duygusal dengesizliğin yüksek yenilikçilik ile ilişkili olmasının beklenebileceğini, duygusal dengesizliğin özelliklerinin güvenli, istikrarlı, endişeli ve strese karşı toleranssız olduğu, yenilikçi davranışı belirleyen faktörlere bakıldığında da benzerlikler bulunabileceğini, ayrıca; değişen çevrelerin, inovasyonu ima etmeye, strese ve kaygıya yol açabileceği bildirilmiştir (Bakx, 2007). Konuyla ilgili literatür taraması 1şı̆̆ında araştırmamızda duygusal dengesizliğin bireysel inovasyon davranışı ile ilişkili olabileceği kanısı oluşmaktadır. Olumlu bireysel inovasyon algısı yüksek bireylerin inovasyon davranışlarının da istenilen seviyelerde olacağ kişilik özellikleri ile bireysel inovasyon davranışı arasında aracılık etkisinin olacağı öngörülmektedir. Ayrıca; direnç bireysel inovasyon algısı düşük bireylerin inovasyon davranışlarının da istenilen seviyelerde olacağı ve beş faktör kişilik özellikleri ile bireysel inovasyon davranışı arasında aracılık etkisinin olacağı da öngörülmektedir. Bunun dışında olumsuz bireysel inovasyon algısı düşük bireylerin inovasyon davranışlarının da istenilen seviyelerde olacağı ve beş faktör kişilik özellikleri ile bireysel inovasyon davranışı arasında aracılık etkisinin olacağı da öngörülmektedir. Yukarıdaki bilgiler 1şığında mevcut araştırma kapsamında aşağıda sıralanan hipotezler kurulmuştur. H1 "Aş̧̧ların beş faktör kişilik özellikleri ile bireysel inovasyon davranışları arasında pozitif yönlü bir ilişki vardır." H1a:"Açıklık kişilik özelliği ile bireysel inovasyon davranışı arasında pozitif yönlü bir ilişki vardır". H1b: "Sorumluluk kişilik özelliği ile bireysel inovasyon davranışı arasında negatif yönlü bir ilişki vardır". H1c: "Dışa Dönüklülük kişilik özelliği ile bireysel inovasyon davranışı arasında pozitif yönlü bir ilişki vardır". H1d: "Uyumluluk kişilik özelliği ile bireysel inovasyon davranışı arasında negatif yönlü bir ilişki vardır". H1e: "Duygusal Dengesizlik (Nevrotiklik) kişilik özelliği ile bireysel inovasyon 


\section{S. A. Çetin - B. Şahin 11/1 (2019) 706-719}

davranışı arasında pozitif yönlü bir ilişki vardır". H2: "Bireysel inovasyon olumlu algı boyutu beş faktör kişilik özellikleri ile bireysel inovasyon davranışı arasında aracıllk etmektedir". H3: "Bireysel inovasyon olumsuz algı boyutu beş faktör kişilik özellikleri ile bireysel inovasyon davranışı arasında aracıllk etmektedir". H4:"Bireysel inovasyon direnç algı boyutu beş faktör kişilik özellikleri ile bireysel inovasyon davranışı arasında aracılık etmektedir".

\section{YÖNTEM}

Araştırma Modeli: Mevcut araştırmada literatürden yola çıkılarak otel mutfaklarında çalışan aşçların beş faktör kişilik özellikleri, bireysel inovasyon algısı ve bireysel inovasyon davranışı ilişkileri baz alındığı için betimsel araştırma modeli kullanılmıştır. Araştırma nicel özellikler sunmaktadır.

Evren ve Örneklem: Bu araştırmanın kuramsal çerçevesi ulaşılabilen alan yazın; uygulaması ise Bursa ili ile sınırlı tutulmuştur. Evrenin tamamına yönelik kesin bir (istatistiki) veri elde edilemediğinden dolayı evrene ulaşmak adına Bursa'da bulunan aşçılar derneği başkanları ziyaret edilmiş dört ve beş yıldızlı otellerde çalışan üyelerininin listesi alınmıştır. Bu üyelerin referansıyla ilgili otellerin aşçbaşıları ile görüşülmüş ve ölçek formları hakkında kısa bilgiler verilmiştir. Personel sayısı sorularak not edilmiş ve ilgili personel sayısı kadar anket formu bırakılarak gönüllü personellerine verilen bilgiler doğrultusunda yüz yüze uygulatması istenmiştir. Araştırma kapsamında katılımcıların kimliklerine ilişkin bilgiler istenmemiş ve gizlilik ilkesine bağlı kalınacağı belirtilmiştir. Ayrıca; gönüllü olan 18 yaş üstü katılımcılara ölçekleri cevaplandırması için yaklaşık 15-20 dakika süre verilmesi istenmiştir. Bu sayede evrene ulaşılmaya çalışılmıştır. 22 oteldeki toplam aşçı sayısı 281'dir. Dağıtılan anketlerden 246'sı geri dönmüştür. Geri dönüş oranı \%87,5'dir. Ancak; araştırma sonuçlarını etkileyecek veri içeren 26 anket kapsam dışı tutularak 220 anket analize değer bulunmuştur. Araştırma kapsamında toplanan nicel veriler, 2017 Temmuz ve Ağustos ayları içinde elde edilmiştir.

Veri Toplama Araçları: Katılımcılara ilişkin demografik bilgileri toplamak amacıyla araştırmacılar tarafından hazırlanan bu formda, katılımcıların cinsiyeti, yaşı, çalışılan alandaki tecrübesi, çalışılan işletmedeki tecrübesi, görevi ve eğitim düzeyi vb. demografik bilgileri sorgulanmıştır. Beş faktör kişilik özellikleri ile ilgili olarak John ve Srivastava, (1999) çalışmasındaki 44 ifadeden oluşan ölçeğin birebir çevirisi yapılarak tercih edilmiştir. Bu konuda turizm konusunda da bilgi sahibi birbirinden habersiz 3 uzmana başvurulmuştur. Beş faktör kişilik özelliklerinin tüm ifadeleri dikkate alındığında $\alpha=.781$ olarak bulunmuştur. Alt boyutların cronbach alfa değerleri deneyime açıklık .710, Uyumluluk .634, Sorumluluk .726 , dışadönüklük .550 ve duygusal dengesizlik .525 olarak bulunmuştur. Bu oranların 1'e yakın olması ölçeğin daha güvenilir olduğunu göstermektedir. Bireysel İnovasyon Algısı ile ilgili kullanılan ölçek Taşgit ve Torun, (2016) tarafından gerçekleştirilen çalışmadan alınmıştır. Ölçek 10 ifadeden oluşmaktadır. Bireysel inovasyon algısı unsurlarının üç boyuttan (olumlu alg1, olumsuz algı, direnç algısı) oluştuğu belirlenmiştir. Tüm bireysel inovasyon algısının yer aldığı ifadeler analize dahil edildiğinde $\alpha=.683$ olarak bulunmuştur. Alt boyutların güvenirlik analizi sonuçları incelendiğinde, Olumlu Bireysel İnovasyon Algısı ölçeği $\alpha=.636$, Olumsuz Bireysel İnovasyon Alg1sı ölçeği $\alpha=.596$ ve Direnç Bireysel İnovasyon Algisı ölçeği $\alpha=.501$ olarak bulunmuştur. Hurt, Joseph ve Cook, (1977) tarafından geliştirilen özgün form Kılıçer ve Odabaşı, (2010) çalışmasının temelini oluşturmuş ve toplamda 20 ifade olan bireysel inovasyon davranışı ölçeği bu çalışmada da kullanılmıştır. Ancak; bu çalışmada aynı yöntemi izlemek yerine ölçeği oluşturan ifadeler açıklayıcı faktör analizine tabi tutulmuş ve ortaya çıkan beş boyutun orijinal çalışmadaki (Yenilikçi, Öncü, Sorgulayıcı, Şüpheci, Gelenekçi) boyutlarıyla isimlendirebilecek şekilde benzerlik gösterdiği tespit edilmiştir. Bireysel inovasyon davranışını içeren tüm ifadelerin güvenirlik katsayısı .789 olarak bulunmuştur. Alt boyutların $\alpha$ değerleri yenilikçi davranış $\alpha=.858$, öncü inovasyon davranışı $\alpha=.673$, sorgulayıcı inovasyon davranışı $\alpha=.610$, şüpheci inovasyon davranışı $\alpha=.574$, gelenekçi inovasyon davranışı $\alpha=.306$ olarak tespit edilmiştir. Kişisel bilgi formu hariç anket formunu oluşturan tüm ölçek ifadeleri için beşli Likert ölçeği kullanılmıştır.

Verilerin Analizi: Ölçeklerden elde edilen veriler IBM SPSS 22.0 for Windows istatistik paket programı kullanılarak analiz edilmiştir. Veri analizi birkaç aşamadan oluşmaktadır. Öncelikle veriler tasnif edilmiş, ardından uç değerler ve hatalı veri girilip girilmediği kontrol edilmiştir. Uç değerlerin tespiti aşamasında Mahalanobis mesafesi hesaplanmış ve uç değer içeren anket formu tespit edilmemiştir. Regresyon analizi, normal dağılım yaklaşımını esas aldığı için araştırmada kullanılan ölçeklere ilişkin çarpıklık (skewness) ve basıklık (kurtosis) katsayıları incelenmiştir. Çarpıklık ve basıklık katsayıları, normal dağılımdan sapmayı 
gösteren değerlerdir. Her iki katsayının da \pm 2 değerini aşmaması gerekmektedir (Kunan, 1998; Klein, 2011 akt., Uşaklı, 2017 :161). Bu araştırmada ilgili değişkenlerin çarpıklık değerlerinin $-0,270$ ile $+0,275$; basıklık değerlerinin ise $-0,319$ ile $+0,388$ arasında değiştiği belirlenmiştir. Dolayısıyla, verilerin normal dağılımı ile ilgili herhangi bir sorunla karşılaşılmamıştır. İlgili kontroller tamamlandıktan sonra, ölçeklerin (bireysel inovasyon algısı ve bireysel inovasyon davranışı) yapı geçerliklerini ve önde gelen alt boyutlarını tespit etmek amacıyla Açıklayıcı Faktör Analizi kullanılmıştır. Faktör analizi, Temel Bileşenler Analizi (Principal Component Analysis) yöntemi ve Kaiser Normalizasyonlu Varimax dik döndürme yöntemi kullanılarak gerçekleştirilmiştir. Eigen Value değeri 1 ve üzeri olarak kullanılmıştır. Faktör analizi sonuçlarını değerlendirmede temel ölçüt faktör yükleridir. Faktör altında yer alan ifadelerin tespit edilmesi aşamasında, ifadelerin her bir faktör için aldıkları faktör yüklerine bakılmaktadır. Bu nedenle, bir ifadenin bir faktörde yer alabilmesi için en azından 0.50'lik faktör yüküne yakın ve üstünde olması gerekli görülmüştür. Ayrıca; bir faktör altında yer alan ifadenin, bir başka faktör altında da yüksek faktör yüküne (0.40) sahip olması durumunda (cross-loading), ilgili ifadenin çıkarılması gerektiği önerilmektedir (Uşaklı, 2017 :155). Bartlett Küresellik Testi (Barlett's Test of Sphericity) sonuçları, değişkenler arasında faktör analizi yapmaya yeterli düzeyde ilişki olduğunu göstermektedir (tüm $\mathrm{p}$ değerleri anlamlı, p=.000). Kaiser-Meyer-Olkin örneklem yeterliliği ölçüsünün yüksek olması (tüm analizlerde ilgili ölçü > 0.700), toplanan veri setinin faktör analizi yapmaya uygun olduğunu göstermektedir. Faktör analizinde, özdeğeri (eigenvalue) 1'den büyük faktörler kullanılmıştır. Faktörlerin isimlendirilmesi aşamasında faktör yükleri ve her bir faktör altında yer alan maddenin o faktörün bütünü ile ilişkisi kriterleri kullanılmıştır. Pearson Korelasyonu ve Çoklu Regresyon Analizleri ile hipotezler test edilmiştir. Bireysel inovasyon algısının aracılık etkisini test etmek için bağımsız değişkenin (beş faktör kişilik özellikleri) bağımlı değişken (bireysel inovasyon davranışı) üzerindeki doğrudan, dolaylı ve toplam etkileri birlikte incelenmiştir. Geleneksel olarak aracılık etkisi, Baron ve Kenny (1986) tarafından önerilen regresyon analizleri ile test edilmektedir. Aracllık etkisinin tespitinde, Zhao vd. (2010) tarafından geliştirilen aracılık sınıflandırması kullanılmıştır.

\section{BULGULAR}

Araştırmaya katılan aşçıların \%77,7'si erkek, \%22,3'ü kadındır. Katılımcıların büyük bir çoğunluğunun (\% 68,6) 35 yaşından küçük olduğu belirlenmiştir. Katılımcıların yarıya yakınının (\% 44,5) alanlarında 10 yıl ve daha fazla tecrübeye sahip oldukları, çalışılan işletme bazında \% 43,2'sinin 1 yıldan az tecrübeye, \% 29,1'inin ise 1-5 yıl arası çalışılan işletme tecrübesine sahip oldukları tespit edilmiştir. Katılımcıların çalıştıkları işletmelerdeki görevlerine göre dağılımları incelendiğinde, ilk üç iş grubunun sırasıyla aşçı yardımcısı $(\% 39,1)$, aşçı $(\% 25,5)$ ve kısım şefi $(\% 19,5)$ olduğu belirlenmiştir. Öğrenim durumu dağılımına bakıldığında ise çoğunluğun \%40,9 ile lise ve dengi öğrenime sahip bireylerden oluştuğu tespit edilmiştir. Yüksekokul düzeyinde bir öğrenime sahip olanlar \%24,1'dir. Yapılan açıklayıcı faktör analizi sonucu bireysel inovasyon algısının üç boyuttan oluştuğu (olumlu, olumsuz ve direnç) bulunmuştur. İfadelerin en az 0.50 faktör yüküne sahip olduğu ve birden fazla faktör altında yer alan ifade olmadığı tespit edilmiştir. İlgili değerler Tablo 1'de sunulmuştur.

Tablo 1. Bireysel İnovasyon Algısına Yönelik Açıklayıcı Faktör Analizi Sonuçları

\begin{tabular}{|c|c|c|c|c|}
\hline \multirow{14}{*}{ 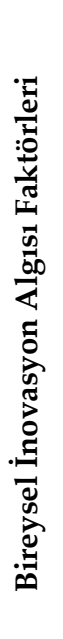 } & \multirow[t]{5}{*}{$\begin{array}{l}\text { Faktör Adı } \\
\text { Olumlu Alg1 }\end{array}$} & \multicolumn{2}{|r|}{ Faktör Yükü } & $\begin{array}{c}\text { Açılanan Varyans (\%) } \\
26.594\end{array}$ \\
\hline & & OA1 & .820 & \\
\hline & & OA2 & .803 & \\
\hline & & DA7 & .530 & \\
\hline & & OA10 & .524 & \\
\hline & \multirow[t]{5}{*}{ Olumsuz Alg1 } & & & 16.573 \\
\hline & & OLSA3 & .537 & \\
\hline & & OLSA4 & .761 & \\
\hline & & OLSA5 & .775 & \\
\hline & & OLSA6 & .550 & \\
\hline & \multirow[t]{3}{*}{ Direnç Algisı } & & & 10.995 \\
\hline & & DA8 & .570 & \\
\hline & & DA9 & .819 & \\
\hline & \multicolumn{2}{|c|}{ Toplam Açıklanan Varyans (\%) 54.162} & KMO. Örn. Yet. & Ölç. .711 \\
\hline & \multicolumn{3}{|c|}{ Bartlett Küresellik Testi Ki Kare 321,883; sd= 45; p=.000 } & \\
\hline
\end{tabular}




\section{S. A. Çetin - B. Şahin 11/1 (2019) 706-719}

Açıklayıcı faktör analizi sonucunda bireysel inovasyon davranışının beş boyuttan oluştuğu bulunmuştur. Tüm ifadeler kabul edilebilir değere yakın ve üstünde olduğundan analizlerde kullanılmıştır. Açıklayıcı faktör analizine ilişkin değerler Tablo 2' de sunulmuştur.

Tablo 2. Bireysel İnovasyon Davranışına Yönelik Açıklayıcı Faktör Analizi Sonuçları

\begin{tabular}{|c|c|c|c|c|}
\hline & Faktör Adı & İfade No & Faktör Yükü & $\begin{array}{c}\text { Açıklanan } \\
\text { Varyans (\%) }\end{array}$ \\
\hline \multirow{26}{*}{ 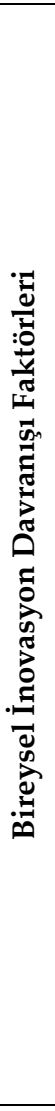 } & Yenilikçi & & & 19,329 \\
\hline & & YEN11 & .666 & \\
\hline & & YEN12 & .833 & \\
\hline & & YEN13 & .751 & \\
\hline & & YEN18 & .637 & \\
\hline & & YEN19 & .536 & \\
\hline & & YEN28 & .744 & \\
\hline & & YEN29 & .695 & \\
\hline & Öncü & & & 10,828 \\
\hline & & ÖNC15 & .478 & \\
\hline & & ÖNC21 & .700 & \\
\hline & & ÖNC22 & .643 & \\
\hline & & ÖNC24 & .612 & \\
\hline & & ÖNC26 & .488 & \\
\hline & Sorgulayıcı & & & 10,719 \\
\hline & & SOR16R & .742 & \\
\hline & & SOR20R & .631 & \\
\hline & & SOR25R & .638 & \\
\hline & & SOR30R & .538 & \\
\hline & Şüpheci & & & 9,181 \\
\hline & & ŞÜP23R & .776 & \\
\hline & & ŞÜP27R & .742 & \\
\hline & & ŞÜP17R & .613 & \\
\hline & Gelenekçi & & & 6,480 \\
\hline & & GEL14R & .709 & \\
\hline & Bartlett Küresellik Testi & & Ki Kare 1222,122; & $\mathrm{sd} .=190 ; \mathrm{P}=.000$ \\
\hline
\end{tabular}

Beş faktör kişilik özellikleri ile bireysel inovasyon davranışı arasındaki korelasyan katsayısı $(\mathrm{r}=.366)$ 0,01 düzeyinde anlamlı bulunmuştur. Bireysel inovasyon davranışını en çok etkileyen beş faktör kişilik özelliklerinin neler olduğuna ilişkin çok değişkenli regresyon analizi yapılmış ve ilgili değerler Tablo 2'de görülmektedir. Analiz sonucunda $\mathrm{F}=8.405$ ve $\mathrm{p}<.000$ olarak tespit edilmiştir. Açıklık, Sorumluluk, Dışadönüklük, Uyumluluk ve Duygusal Dengesizlik bağımsız değişkenleri bağımlı değişkendeki (bireysel inovasyon davranışı) değişimin ( $R^{2}=.207$ olduğu için) \%20,7'sini açıklamaktadır. Modelde yer alan değişkenlerden sorumluluk ve uyumluluk, bireysel inovasyon davranışı ile negatif ilişkili öngörülmüş ancak; istatistiksel olarak anlamsız pozitif ilişkili (sorumluluk Beta $=.124, \mathrm{p}=.272$ ), (uyumluluk Beta $=.009$, $\mathrm{p}=$.932) bulunmuştur. Açıklık, Dışadönüklük ve duygusal dengesizlik bireysel inovasyon davranışı ile pozitif ilişkili öngörülmüş ancak; duygusal dengesizlik negatif ilişkili (Beta $=-.217, p=.017$ ) istatistiksel olarak anlamlı iken dışadönüklük de pozitif ilişkili öngörülmüş ancak; negatif ilişkili bulunmuş ve istatistiksel olarak da (Beta $=-.053, \mathrm{p}=.592)$ anlamlı bulunmamıştır. Bireysel inovasyon davranışı ile düşük pozitif ilişkili ve istatistiksel olarak anlamlı olan tek beş faktör kişilik özellikleri boyutu "açıklı" (Beta = .275, $\mathrm{p}=.007$ ) olarak bulunmuştur. Bu modele göre yukarıdaki tabloda görüldüğü gibi $ß=.229$ ve Beta= \%27.5 olduğu için bağımlı değişken bireysel inovasyon davranışını açıklayıcılık açısından pozitif yönde en açıklayıcı bağımsız değişkenin, "açıklık", olduğunu anlamak mümkündür. Tablo 3'teki beş faktör kişilik özellikleri boyutlarının bireysel inovasyon davranışı üzerindeki etkilerinin incelendiği bu çok değişkenli regresyon analizi sonuçları dikkate alındığında $H 1$ ve $H 1 a$ hipotezi desteklenmiştir. H1b, H1c, H1d ve H1e hipotezleri ise desteklenmemiştir. 
S. A. Çetin - B. Şahin 11/1 (2019) 706-719

Tablo 3. H1 ve Alt Hipotezlerine Yönelik Çok Değişkenli Regresyon Analizi Sonuçları

\begin{tabular}{llccccccccc}
\hline $\begin{array}{l}\text { Hipotez } \\
\text { Sırası }\end{array}$ & Model 1 & $\mathbf{B}$ & Beta & $\mathbf{t}$ & $\mathbf{( t - p . )}$ & $\mathbf{R}$ & $\mathbf{R}^{\mathbf{2}}$ & $\begin{array}{c}\text { Uyarl. } \\
\mathbf{R}^{\mathbf{2}}\end{array}$ & $\mathbf{F}$ & $\mathbf{p}$ \\
& Constant & 2.967 & & 6.536 & .000 & & & & & \\
H1 ve & Aç1klı & .229 & .275 & 2.722 & .007 & & & & & \\
H1a & Sorumluluk & .093 & .124 & 1.102 & .272 & & & & & \\
H1b, & Dişadönüklük & -.045 & -.053 & -.537 & .592 & .455 & .207 & .182 & 8.405 & .000 \\
H1c, & Uyumluluk & .007 & .009 & .086 & .932 & & & & & \\
H1d & Duygusal & -.177 & -217 & -2.419 & .017 & & & & & \\
H1e & Dengesizlik & -.017 & & & & & & & \\
\hline
\end{tabular}

a Bağımsız Değişkenler: Açıklık, Sorumluluk, Dışadönüklük, Uyumluluk, Duygusal Dengesizlik

b Bağımlı Değişken: Bireysel İnovasyon Davranışı

Aracılık etkisinden söz edebilmek için bazı şartların yerine gelmesi gerekmektedir (Baron ve Kenny, 1986, akt., Uşaklı, 2017 :193): Bağımsız değişkenin düzeyindeki değişimler (varyasyonlar), bağımlı değişkendeki değişimlerin nedenini anlamlı bir şekilde açıklamalıdır (Yol a), Bağımsız değişkendeki değişimler, aracı değişkendeki değişimlerin nedenini anlamlı bir şekilde açıklamalıdır (Yol b), a ve b yolları kontrol altında tutulduğunda, daha önceden bağımsız değişken ve bağımlı değişken arasındaki anlamlı ilişki (Yol c), artık ya tamamen anlamsız hale gelmeli (tam aracılık) ya da etki düzeyi azalmalıdır (kısmi aracılık). Yol (a) veya yol (b) anlamsız ise analize devam edilmez ve aracısızlık ya da etkisizlik olarak değerlendirilir. Tablo 41. aşamada görüldüğü üzere 1. ön şart olan bağımsız değişkenin bağımlı değişken üzerindeki doğrudan etkisi (Beta $=.366$ ve $\mathrm{p}=.000$ ) anlamlıdır ve bu yüzden 1. şart karşılanmıştır. Tablo 4 2. aşamada bağımsız değişkenin aracı değişken üzerindeki etkisi anlamlı olup (Beta=.367 ve p=.000) bir sonraki aşamaya geçilmiştir. Tablo 43. aşamada görüldüğü üzere bağımsız ve aracı değişkenin dahil edildiğinde bağımlı değişken üzerindeki etkisi de anlamlıdır (Beta=.297 ve $\mathrm{p}=.000$ ). 1 . aşamadaki anlamlı beş faktör kişilik özellikleri bağımsız değişkeni Beta $=.366, p=.000$ iken 3. aşamada Beta $=.297, p=.000$ olarak etkisi azalmıştır. Bu durum, beş faktör kişilik özelliklerinin bireysel inovasyon davranışı üzerindeki etkisinde aracı değişken olumlu bireysel inovasyon algısının "kısmi aracılık etkisi" yaptığını göstermektedir. Sobel Testinin anlamlı çıkması (Z= 2.603, p=.0092) algılanan bireysel inovasyon değişkeninin söz konu değişkenler arasındaki kısmi aracılık etkisinin varlığını doğrulamaktadır. Bu sonuçlara göre H2 hipotezi desteklenmiştir.

Tablo 4. H2 Hipotezine Yönelik Çok Değişkenli Regresyon Analizi Sonuçları

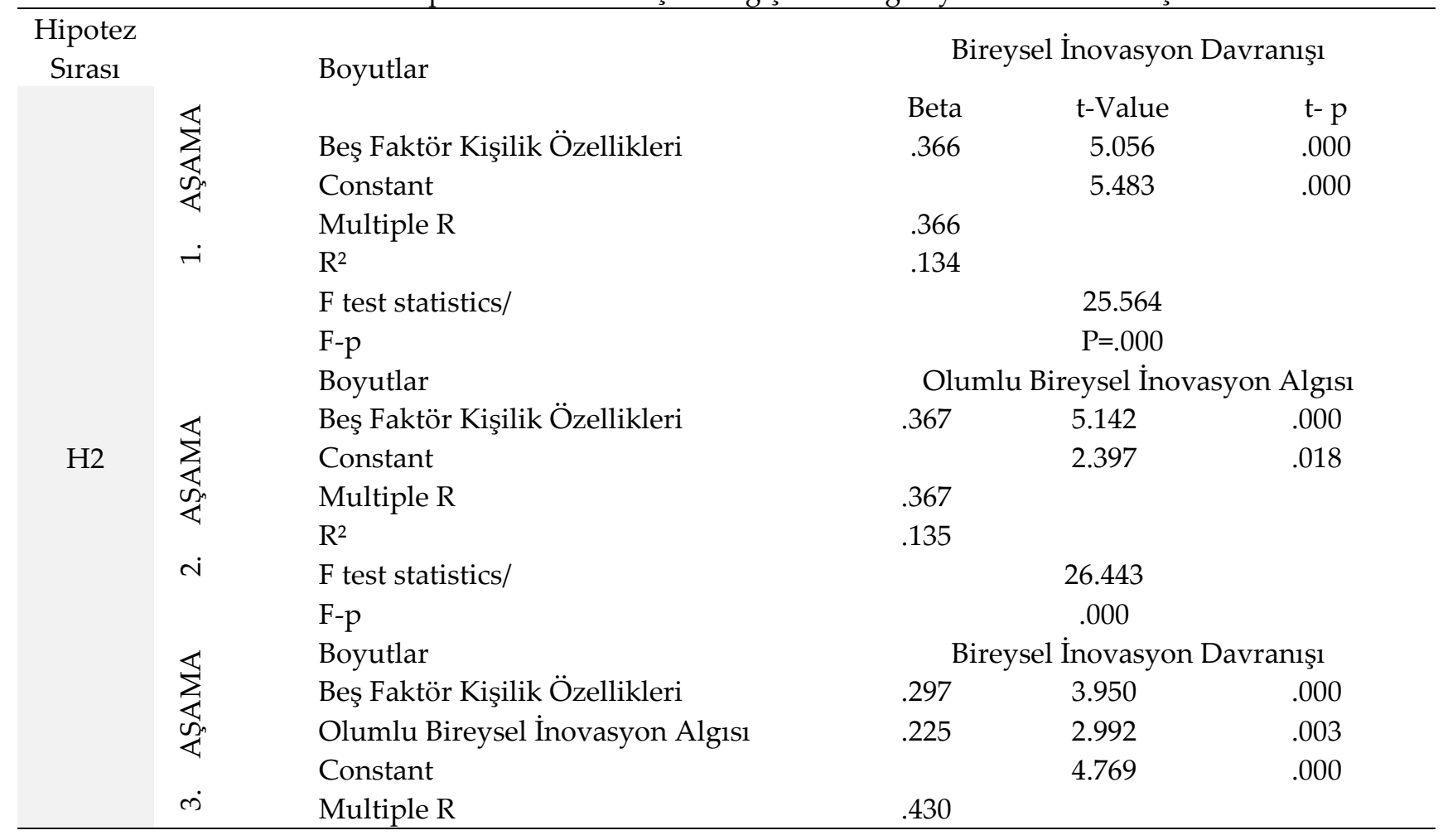




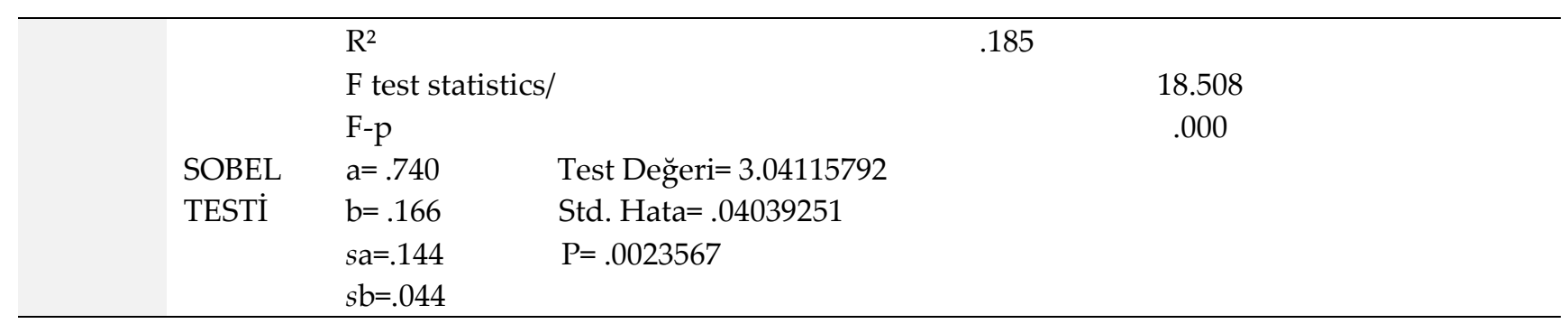

Tablo 5'te de görüldüğü üzere olumsuz bireysel inovasyon algısının aracılık etkisinden bahsedebilmek için 1. ön şart olan bağımsız değişkenin bağımlı değişken üzerindeki doğrudan etkisi (Beta=.366 ve p=.000) anlamlıdır ve bu yüzden 1. şart karşılanmıştır. Tablo 5'te 2. aşamada görüldüğü üzere bağımsız değişkenin aracı değişken üzerindeki etkisi anlamsız olup (Beta=.140 ve $\mathrm{p}=.067$ ) bir sonraki aşama olan bağımsız değişken ve aracı değişkenin birlikte bağımlı değişken üzerindeki doğrudan etkilerine bakılması aşamasına geçilememiştir ve sobel testinin yapılmasına gerek kalmamıştır. Bu durumda aracılıktan söz edebilmek mümkün olmamaktadır, dolayısıyla H3 hipotezi desteklenmemiştir. Tablo 5'te H4 satırında da görüldüğü üzere direnç bireysel inovasyon algısının aracılık etkisinden bahsedebilmek için 1. ön şart olan bağımsız değişkenin bağımlı değişken üzerindeki doğrudan etkisi (Beta=.366 ve p=.000) anlamlıdır ve ikinci önşart olan bağımsız değişkenin aracı değişken üzerindeki dolaylı etkisinin anlamlı olup olmadığına bakılmıştır. Bu etki anlamsız olup (Beta=.118 ve $p=.124$ ) son aşama toplam etkiye bakılması aşamasına geçilememiştir ve sobel testinin yapılmasına da gerek kalmamıştır. Bu sonuçlara göre $\mathrm{H} 4$ hipotezi desteklenmemiştir.

Tablo 5. H3 ve H4 Hipotezlerine Yönelik Çok Değişkenli Regresyon Analizi Sonuçları

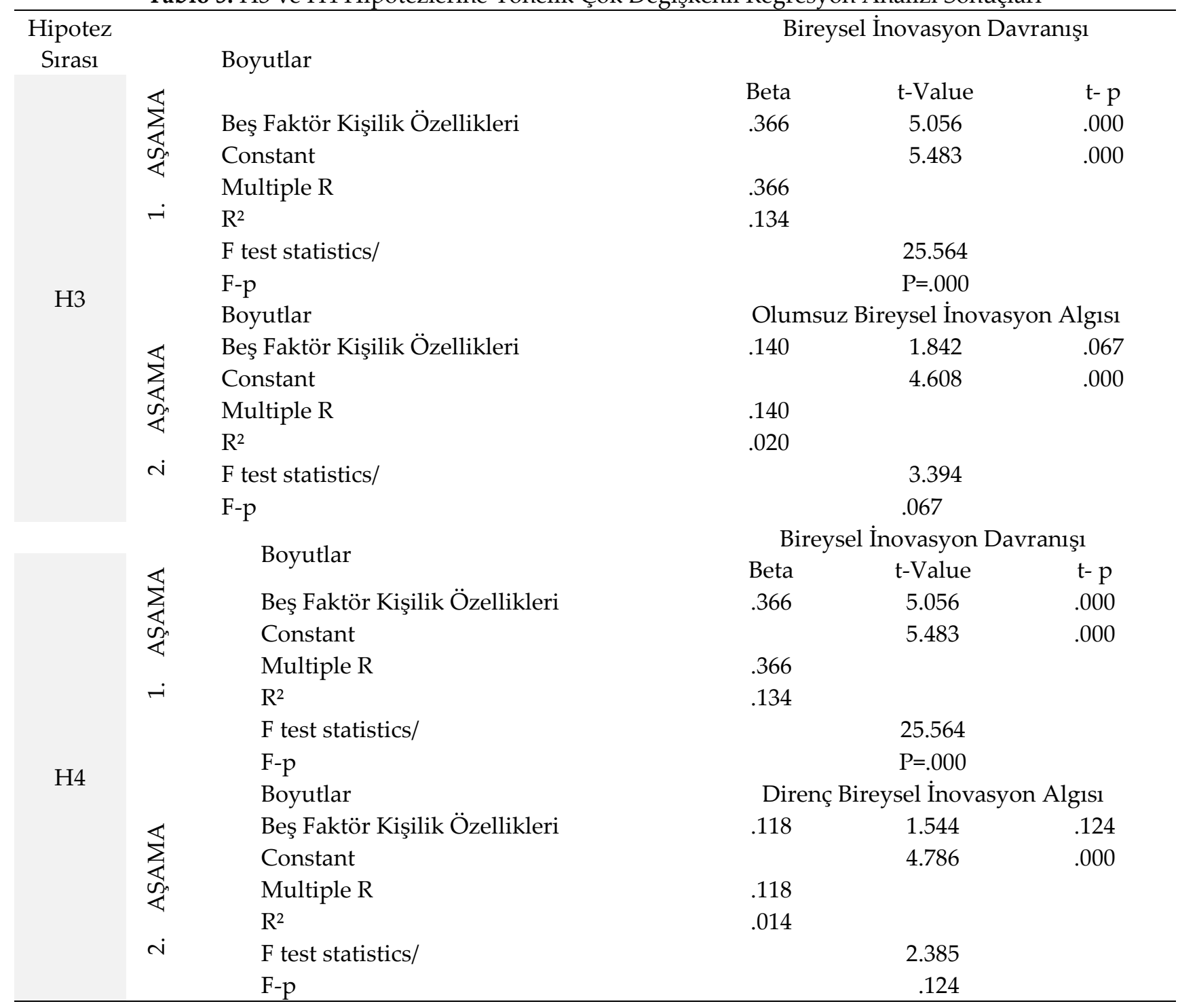




\section{Sonuç ve Tartışma}

Mevcut araştırmada, beş faktör kişilik özelliklerinin bireysel inovasyon davranışını pozitif yönde etkilediği tespit edilmiştir. Buna göre, beş faktör kişilik özelliklerini oluşturan beş faktörden sadece ikisinin (deneyime açıklık ve duygusal dengesizlik) bireysel inovasyon davranışı üzerinde anlamlı etkisi bulunmaktadır. Dolayısıyla, literatürde öne sürülen beş faktör kişilik özellikleri ile bireysel inovasyon davranışı ilişkisi, mevcut araştırma bulguları ile desteklenmiş olup; bağımlı değişken bireysel inovasyon davranışını açıklayıcılık açısından pozitif yönde en açıklayıcı bağımsız değişkenin, "açıklık" olduğu, negatif yönde en açıklayıcı bağımsız değişkenin ise "duygusal dengesizlik" olduğu bulunmuştur. Bir başka deyişle deneyime açık bireylerin bireysel inovasyon davranışlarını olumlu yönde etkilediği, duygusal dengesizlik özelliğine sahip olanların ise olumsuz yönde etkilediği sonucuna varılmaktadır. Bu sonuç, daha önceki çalışmaların (Bakx, 2007; Yeşil ve Sözbilir, 2013) bulgularıyla tutarlılık göstermektedir. Geniş katılımlı farklı bir örneklem üzerinde benzer sonuçlara ulaşılması daha önceki çalışmaların devamı niteliğinde olup bu kapsamda literatüre katkı sağlamaktadır. Mevcut araştırmada olumlu bireysel inovasyon algısının beş faktör kişilik özellikleri ile bireysel inovasyon davranışı arasındaki ilişkide "kısmi aracılık" etkisi taşıdığı tespit edilmiştir. Diğer bir ifadeyle, kişilik özelliklerinin, olumlu bireysel inovasyon algısı aracılığıyla, bireysel inovasyon davranışı üzerinde dolaylı bir etkisi daha bulunmaktadır. Bu durum öngörüsel beklenti ile uyumlu olup, bireysel inovasyon algısının aracılık etkisinin konuyla ilgili önceki çalışmalarda araştırılmamış olmasından dolayı litaratüre katkısı özgünlük taşımaktadır. Şüphesiz olumlu inovasyon algıları aşçıların bireysel inovasyon davranışlarını da olumlu yönde etkileyecektir. Bu durum beklenen inovatif davranışlarda inovasyon algılarının dikkate alınması gerektiğini ortaya koymaktadır. Dolayısıyla, otel işletme yöneticilerinin; kişilik özellikleri, olumlu bireysel inovasyon algısı, bireysel inovasyon davranışı ilişkisine bütüncül olarak yaklaşmaları ve faaliyetlerini buna uygun olarak düzenlemeleri önerilmektedir. Bu öneriler, inovatif davranış gerektiren mutfak pozisyonlarının belirlenmesi, kendisinden inovatif bir takım davranışlar beklenilen personel seçiminde kişilik özelliklerinin yanında olumlu bireysel inovasyon algısına sahip kişilerin de seçilmesi için mevcut çalışmadaki ölçeklerin ve benzeri ölçeklerin kullanılması, hali hazırda işletmelerde çalışan personellerin kişisel gelişimine özellikle yaratıcılığına etki edecek esneklik sağlanması ve bir takım denemeler yapacak imkanların tanınması şeklinde olabilir. Bunun yanında aşçıların yaratıcılığına katkı yapacak, başkalarıyla etkileşim içinde olacağı kongre, seminer, fuar, yarışma gibi etkinliklere katılımı teşvik edilmeli ve gerekli katkı sağlanmalıdır. Yaptıkları yemeklerle kişiliklerinden birşeyler ortaya koyan aşçıların inovasyon algılarının yüksek olması daha sık inovatif davranışıyla kendini göstermektedir. Elbette bireysel inisiyatifleri de bu davranışlarda etkili olabilmektedir. Mevcut çalışmada inisiyatif kavramı ele alınmamıştır ancak; ileriki çalışmalarda bireysel inovasyon algısıyla beraber aracılık etkisi çalışılabilir. Bunun yanında örgütsel adalet, örgütsel vatandaşlık kavramlarının da kişilik -inovasyon davranışı ilişkisinde aracılık rolleri sorgulanabilir. Ayrıca; farklı ülkelerdeki (örneğin, Akdeniz çanağındaki ülkeler) beş faktör kişilik özelliklerini, bireysel inovasyon algı ve davranışlarını karşılaştırmalı olarak gelecekte incelenmesi düşünülen çalışmalar; ilgili değişkenlerin daha iyi anlaşılmasına katkıda bulunacaktır. Bu araştırma, Bursa ilindeki çoğunlukla şehir otelciliği kapsamında hizmet veren dört ve beş yıldızlı oteller ile sınırlı tutulmuştur. Kıyı turizmine yönelik otellerde bulunan personel yoğunluğunun fazla olduğu ve bu otellerde daha çok yabancı turiste hizmet edildiği bilinmektedir. Bu tür otellerde çalışan aşçıların daha yoğun çalıştığı ve kişilik özelliklerinin bu yoğun ve stresli ortamda önemli farklılıklar oluşturabileceği düşünülmektedir. Bundan dolayı da bu tarz otellerdeki aşçların kişilik bireysel inovasyon ilişkisinin incelenmesi önem arz etmektedir. Araştırma evrenine yönelik istatistiki bir veri olmadığı için bu araştırmada, dört ve beş yıldızlı otellerde çalışan aşçıların tamamına ulaşılmaya çalışılmıştır. Ancak; yine de geri dönüş sayısındaki eksiklikler ve araştırmanın amacına hizmet etmeyecek derecede eksik, yanlış ve uç değer kodlamalarından dolayı bu durum, araştırma bulgularının genellenebilirliğini sınırlandırmaktadır. Araştırma evrenine yönelik tam sayım yöntemi ile yapılacak olan çalışmalarda daha sınırı bir hedef kitle seçen ve bu hedef kitle üzerinde olasılıklı örnekleme yöntemlerini kullanan araştırmacılar; elde edecekleri sonuçların genellenebilirliğini daha da arttırabilirler. İlgili araştırmalar incelendiğinde, beş faktör kişilik özellikleri ve bireysel inovasyon davranışını inceleyen nitel çalışmaların oldukça az olduğu belirlenmiştir. Bu iki değişkenin daha iyi incelenmesi ve özgün katılımcı görüşlerine daha fazla yer verilmesi amacıyla, hem nitel hem de nicel yöntemlerin birlikte kullanıldı̆̆ı karma çalışmalara daha fazla ağırlık verilmelidir. Ayrıca; ölçekte kişilik ile ilgili ifadelerin karışık düzende yer alması da önerilmektedir. Çünkü uygulanan ölçeklerde ilk ifadeler deneyime açıklık ile ilgilidir ve çıkan sonuçlarda en fazla anlamlı ilişki de yine aynı 


\section{S. A. Çetin - B. Şahin 11/1 (2019) 706-719}

değişken üzerinedir. Bu durumun tesadüfi olup olmadığı hakkında gelecek araştırmalar daha detaylı sonuçlar üretecektir.

\section{KAYNAKÇA}

Bakx N. (2007). Which Personality Traits Do Innovative People Possess? (Basılmamış Doktora Tezi). Amsterdam: Universiteit van Amsterdam, Business Studies.

Baron, R. M., \& Kenny, D. A. (1986). The moderator-mediator variable distinction in social psychological research: conceptual, strategic, and statistical considerations. Journal of Personality and Social Psychology, 51(6), 1173-1182.

Barrick M.R., ve Mount M.K. (1991). The Big Five Personality Dimensions and Job Performance: a MetaAnalysis, Personnel Psychology, 44: 1-26.

Bunce D. ve West M.A. (1995). Self Perceptions and Perceptions of Group Climate as Predictors of Individual Innovation at Work, Applied Psychology, 44: 199-215.

Chen W.J. (2011). Innovation in Hotel Services: Culture and Personality, International Journal of Hospitality Management, 30: 64-72.

Costa P.T.Jr. ve McCrae R.R. (1992). Four Ways the Five Factors Are Basic, Personality and Individual Differences, 13: 653-665.

Çakıcı C., Çalhan H. ve Karamustafa K. (2016). Yiyecek İçecek İşletmelerinde İnovasyon ve Sürdürülebilir Rekabet Üstünlüğü İlişkisi, Kırıkkale Üniversitesi Sosyal Bilimler Dergisi, 6 (2): 11-39.

Çetin S.A. (2009). Otel İşletmelerindeki İşgörenlerin Örgütsel Adalet Algılamalarının Örgütsel Vatandaşlık Davranışlarına Etkisi Afyonkarahisar'daki 4 ve 5 Yildızlı Termal Otellerde Bir Uygulama (Yayımlanmış Yüksek Lisans Tezi). Kütahya: Dumlupınar Üniversitesi Sosyal Bilimler Enstitüsü.

Demirci, M.K., Özler, D.E. ve Girgin, B. (2007). Beş Faktör Kişilik Modelinin İşyerinde Duygusal Tacize (Mobbing) Etkileri-Hastane İşletmelerinde Bir Uygulama. Journal of Azerbaijani Studies, 10, 13-39.

Elçi, Ş. (2007). İnovasyon Kalkınmanın ve Rekabetin Anahtarı. Ankara: Technopolis Group.

Cengiz, M. (2012). Yenilikçilik Anlayışı, Alanya Bölgesindeki Dört ve Beş Yıldızlı Otellerde Çalışan Yöneticilerin Yenilikçilik Anlayışı (Yayımlanmamış Yüksek Lisans Tezi), Antalya: Akdeniz Üniversitesi Sosyal Bilimler Enstitüsü.

Eraslan H., Bulu M. ve Bakan İ. (2008). Kümelenmeler ve İnovasyona Etkisi: Türk Turizm Sektöründe Uygulamalar, Seyahat ve Otel İşletmeciliği Dergisi, 5 (3): 15-29.

Erdem B., Gökdeniz A. ve Met Ö. (2011). Yenilikçilik ve İşletme Performansı İlişkisi: Antalya'da Etkinlik Gösteren 5 Yıldızlı Otel İşletmeleri Örneği, Dokuz Eylül Üniversitesi İktisadi ve İdari Bilimler Fakültesi Dergisi, 26 (2): 77-112.

Gelade G. (2002). Creative Style, Personality, and Artistic Endeavor, Genetic Social and General Psychology Monographs, 128 (3): 213-234. •

George J. M. ve Zhou J. (2001). When Job Dissatisfaction Leads to Creativity: Encouraging the Expression of Voice, Academy of Management Journal, 44 (4): 682-696.

Girgin, B. (2007). Beş Faktör Kişilik Modelinin İşyerinde Duygusal Tacize (Mobbing) Etkileri (Yayımlanmamış Yüksek Lisans Tezi), Kütahya: Dumlupınar Üniversitesi Sosyal Bilimler Enstitüsü.

Goldberg, L.R. (1993). The Structure of Phenotypic Personality Traits. American Psychologist, 48 (1), 26-34.

Güneş, N. (2016). Beş Faktör Kişilik Özelliklerinin Performansa Etkisi: Yerel Yönetimlerde Bir Uygulama (Yayımlanmamış Yüksek Lisans Tezi), Ankara: Türk Hava Kurumu Üniversitesi Sosyal Bilimler Enstitüsü.

Hurt H. T., Joseph K. ve Cook C. D. (1977). Scales for the Measurement of Innovatiness, Human Communication Research, 4 (1): 58-65. 


\section{S. A. Çetin - B. Şahin 11/1 (2019) 706-719}

Işık C. ve Türkmendağ T. (2016). Atatürk Üniversitesi Turizm Fakültesi Öğrencilerinin Bireysel Yenilikçilik Algılarının Belirlenmesi, Gazi Üniversitesi Turizm Fakültesi Dergisi, 1 (1): 70-99.

John O. P. ve Srivastava S. (1999). The Big Five Trait Taxonomy: History, Measurement, and Theoretical Perspectives, In Pervin, L. A. \& John, O. P. (Eds.), Handbook of Personality: Theory and Research. New York: Guilford Press, 102-138.

Kılıçer K. ve Odabaşı H.F. (2010). Bireysel Yenilikçilik Ölçeği (BYÖ): Türkçeye Uyarlama, Geçerlik ve Güvenirlik Çalışması, Hacettepe Üniversitesi Eğitim Fakültesi Dergisi, 38: 150-164.

Kılıçer, K. (2011). Bilgisayar ve Öğretim Teknolojileri Eğitimi Öğretmen Adaylarının Bireysel Yenilikçilik Profilleri. Yayınlanmamış Doktora Tezi. Anadolu Üniversitesi Eğitim Bilimleri Enstitüsü, Eskişehir.

King L.A., Walker L.M. ve Broyles, S.J. (1996). Creativity and the Five-Factor Model, Journal of Research in Personality, 30 (2): 189-203.

Özçer, N. (2005). Yenilikçilik- Bireysel \& Grupsal. N. Özçer içinde, Yönetimde Yaratıcılık ve Yenilikçilik. Rota Yayınları, İstanbul. 53-55.

Sarıoğlu, A. (2014). Bireysel Yenilikçilik Ölçeğinin Hemşirelikte Geçerlik ve Güvenirliği. Yayımlanmamış Yüksek Lisans Tezi, Atatürk Üniversitesi Sağlık Bilimleri Enstitüsü, Erzurum.

Somer, O. and Goldberg, L.R. (1999). The Structure of Turkish Trait- Descriptive Adjectives. Journal of Personality and Social Psychology, 76, 431-450.

Şentürk, F.K., Durak M., Yılmaz, E., Kaban, T., Kök, N. ve Baş, A. (2016). Dönüşümcü ve Etkileşimci Liderlik Tarzlarının Bireysel Yenilikçiliğe Etkisini Belirlemeye Yönelik Bir Araştırma. Mehmet Akif Ersoy Üniversitesi Sosyal Bilimler Enstitüsü Dergisi, 8 (17), 173-198.

Tajeddini K. ve Trueman M. (2014). Perceptions Of Innovativeness Among Iranian Hotel Managers, Journal of Hospitality and Tourism Technology, 5 (1): 62-77.

Taşgit Y.E. ve Torun B. (2016). Yöneticilerin İnovasyon Alg1sı, İnovasyon Sürecini Yönetme Tarzı ve İşletmelerin İnovasyon Performansı Arasındaki İlişkiler: KOBİler Üzerinde Bir Araştırma, Yönetim Bilimleri Dergisi, 14 (28): 121-156.

Tekin Ö.A. (2012). Yabancılaşma ve Beş Faktör Kişilik Özellikleri Arasındaki İlişkiler: Antalya Kemer'deki Beş Yıldızlı Otel İşletmeleri Çalışanları Üzerinde Bir Uygulama (Basılmamış Doktora Tezi). Antalya: Akdeniz Üniversitesi Sosyal Bilimler Enstitüsü.

Tekin, Y. ve Durna, U. (2012). Otel İşletmelerinde Yenilik Yönetimi Uygulamaları Alanya'da Beş ve Dört Yıldızlı Otel İşletmelerinde Bir Araştırma. Alanya İşletme Fakültesi Dergisi, 4 (3), 93-110.

Torun, B. (2016). İnovasyon Alg1Sı, İnovasyon Sürecindeki Liderlik Tarzları Ve İşletmenin İnovasyon Performansı Arasındaki İlişkiler: Düzce'deki Kobi’ler Üzerinde Bir Araştırma. Yayımlanmamış Yüksek Lisans Tezi, Düzce Üniversitesi Sosyal Bilimler Enstitüsü, Düzce.

Türk Dili Kurumu (2018). Türkçe Sözlük. (Yeni Baskı). Ankara: TDK.

Uşakli A. (2017). Turistik Tüketici Deneyimi: Beş Yıldızlı Resort Otellerde Bir Uygulama (Basılmamış Doktora Tezi). Ankara: Gazi Üniversitesi Eğitim Bilimleri Enstitüsü.

Uzkurt, C. (2010). İnovasyon Yönetimi: İnovasyon Nedir, Nasıl Yapılır ve Nasıl Pazarlanır? Ankara Sanayi Odası Medya Yayın Organı Asomedya, 36-51.

Vatan, A. ve Zengin, B. (2014). Çevresel İnovasyon ve Konaklama İşletmelerindeki Uygulamalar Üzerine Bir Araştırma: İstanbul Örneği. Akademik Sosyal Araştırmalar Dergisi, 2 (8), 511-530.

Yeni, Z. (2015). Beş Faktör Kişilik Özellikleri ile Duygusal Emek Arasındaki İlişkinin Belirlenmesine Yönelik Bir Araştırma (Yayımlanmamış Yüksek Lisans Tezi), Kütahya: Dumlupınar Üniversitesi Sosyal Bilimler Enstitüsü.

Yeşil S. ve Sözbilir F. (2013). An Empirical Investigation into the Impact of Personality on Individual Innovation Behaviour in the Workplace, Social and Behavioral Sciences, 81: 540-551. 


\section{S. A. Çetin - B. Şahin 11/1 (2019) 706-719}

Yıldırım, B.I. (2014). Çalışanların Beş Faktör Kişilik Özellikleri ile İş Tatminleri Arasındaki İlişki: Alanya' daki Beş Yıldızlı Oteller Üzerine Bir Uygulama. (Yayımlanmamış Doktora Tezi), Antalya: Akdeniz Üniversitesi Sosyal Bilimler Enstitüsü.

Yuan, F. and Woodman, R.W. (2010). Innovative Behavior In The Workplace: The Role Of Performance And Image Outcome Expectations. Academy of Management Journal, 53 (2), 323-342.

Zhao X., Lynch JR. J. G. ve Chen Q. (2010). Reconsidering Baron and Kenny: Myths and Truths about Mediation Analysis, Journal of Consumer Research, 37: 197-206. 